\title{
Agroforestry contributions to smallholder farmer food security in Indonesia
}

\author{
Colm Duffy • Gregory G. Toth • Robert P. O. Hagan • Peter C. McKeown • \\ Syed Ajijur Rahman • Yekti Widyaningsih • Terry C. H. Sunderland • \\ Charles Spillane ${ }_{i}$
}

Received: 6 March 2020/ Accepted: 12 March 2021 / Published online: 17 May 2021

(C) The Author(s)

\begin{abstract}
Agroforestry has potential for strengthening the climate change resilience of smallholder farmers in Southeast Asia. In Indonesia, the food security challenges faced by smallholders will likely worsen due to climate change impacts. Agroforestry provides and option for strengthening climate change resilience, while contributing to food access, income, health, and environmental stability. To evaluate the evidence for such benefits, this systematic review identifies 22 peer-reviewed articles published between
\end{abstract}

Colm Duffy and Gregory G. Toth these authors have contributed equally to this paper.

Supplementary Information The online version contains supplementary material available at https://doi.org/10.1007/ s10457-021-00632-8.

C. Duffy · R. P. O. Hagan · P. C. McKeown ·

C. Spillane $(\square)$

Plant and AgriBiosciences Research Centre (PABC),

Ryan Institute, National University of Ireland Galway,

University Road, Galway H91 REW4, Ireland

e-mail: charles.spillane@nuigalway.ie

G. G. Toth

School of Forest Resources and Conservation, University of Florida, Gainesville, USA

S. A. Rahman - T. C. H. Sunderland $(\bowtie)$

Center for International Forestry Research (CIFOR), Jalan

CIFOR, Situ Gede, Sindang Barang, Bogor,

Barat 16115, Indonesia

e-mail: terry.sunderland@ubc.ca
2000 and 2019 which assess agroforestry's contributions to food security in Indonesia, mostly in Java or Sumatra. Analysis of the studies indicate that traditional and commercial agroforestry contribute to food security in diverse ways: for example, traditional homegardens offer $20 \%$ more dietary diversity than commercial counterparts, while commercial homegardens may contribute up to five times more income. Agri-silviculture contributions fall along a timber versus non-timber forest product continuum that displays a similar tradeoff between diversity and income. Those systems with a commercial focus may receive $54 \%$ of their income from a single commodity crop such as coffee, while traditional systems allow greater access to plants with medicinal benefits. Nearly all agroforestry systems offered indirect ben-

\author{
S. A. Rahman \\ Institute of Ecology and Key Laboratory for Earth Surface \\ Processes of the Ministry of Education, College of Urban \\ and Environmental Science, Peking University, \\ Beijing 100871, China \\ Y. Widyaningsih \\ Faculty of Mathematics and Natural Sciences, Universitas \\ Indonesia, Depok, Indonesia \\ T. C. H. Sunderland \\ Faculty of Forestry, University of British Columbia, \\ Vancouver, Canada
}


efits for food security, such as allowing more off-farm work than traditional agriculture and contributing to environmental stability: users of agroforestry were found by one study to collect $83 \%$ less fuelwood from natural forests. One study highlighted that agroforestry options have up to $98 \%$ greater net present value (for periods over 30 years) compared to slash and burn style agriculture. However, very few studies of Indonesian agroforestry focused explicitly on financial analysis and food security, indicating the need for further research. Given the similar situations faced by many Southeast Asia countries, our findings contribute to emerging trends throughout the region regarding the relationship between agroforestry and food security.

Keywords Systematic review - Agroforestry dietary diversity $\cdot$ Southeast Asia $\cdot$ Nutrition .

Agri-silviculture $\cdot$ Homegardens

\section{Introduction}

Food security is when "all people at all times, have physical and economic access to sufficient, safe and nutritious food that meets their dietary needs..." (FAO 1996) in four interrelated categories: availability, accessibility, utilization, and stability (FAO 2008). Food security is a complex issue impacted by and influenced by climate change, natural resource use patterns, and demography (Brown and Funk 2008; Lobell et al. 2008; Wheeler and Von Braun 2013). Food security challenges continue to arise in many parts of Southeast Asia (Mertz et al. 2009). For example, in Indonesia, land conversion, longer dry seasons, extreme temperatures, wildfires, increased incidence of pests and diseases, and floods are contributing to reduced crop yields, and ultimately decreased food access for smallholder farmers (Sutardi and Hilman 2007; World Bank 2011; GOI 2017). Interventions to reduce the vulnerability of smallholders to food security shocks have been widely advocated (e.g. WFP 2015 ). Agroforestry is promoted as one such intervention, that can improve ecosystem services and, when well-planned and implemented, can positively affect health, food access, and income (Nair and Toth 2016; Rosenstock et al. 2016). Agroforestry interventions typically face initial challenges including labor, germplasm and the delayed nature of some of its impacts. While the environmental benefits of agroforestry are well understood, the impacts and outcomes of agroforestry on food security remain less clear. Using targeted search parameters, we have compiled peer-reviewed articles focused on agroforestry contributions to food security in Indonesia, and systematically assessed and mapped the existing literature to the FAO food security pillar framework. The results of our systematic review are presented in the context of agroforestry's potential contributions to food security in Indonesia.

\section{Background}

\section{Country context}

Indonesia comprises approximately 13,450 islands covering some 200 million ha of land, of which $31.5 \%$ is farmland and $51 \%$ is forested (FAO 2015; GOI 2017). Indonesia has the fourth largest population in the world (260 million) spread primarily across its five largest regions (Kalimantan (Indonesian Borneo), Sumatra, Papua (Indonesian New Guinea), Sulawesi, and Java), with a per capita GDP that has risen from US $\$ 807$ in 2000 to US $\$ 3,877$ in 2018 , making it the largest economy in Southeast Asia (FAO and GOI 2017; World Bank 2019). Agriculture is a significant contributor to the Indonesian economy, accounting for circa $13 \%$ of GDP and $30 \%$ of employment-mostly smallholder farmers (ILO 2017; World Bank 2020). Despite Indonesia's economic growth, it faces ongoing challenges in relation to poverty and malnutrition, with $36.1 \%$ of Indonesians living below the poverty line and $30.5 \%$ of those under-five suffering from wasting or stunting (WFP 2015; FAO and GOI 2017; World Bank 2017; UNICEF 2020).

Indonesia's agricultural productivity is significantly influenced by its geography and climate. Located in the humid tropics, the conditions on Indonesia's equatorial islands are relatively similar, with the two main land types comprising coastal lowlands (where temperatures typically remain between $26^{\circ}$ and $32^{\circ}$ Celsius (C), but can reach $38^{\circ} \mathrm{C}$ ) and, to a lesser extent, mountainous highlands (with temperatures averaging between $15^{\circ}$ and $26^{\circ} \mathrm{C}$ ), the volcanic nature of which has contributed to the primarily lateritic soils throughout (Tan 2008). 
Precipitation is heavy throughout the year, with western monsoons providing the greatest rainfall between December and March, and eastern monsoons between June and August. Rainfall averages 3000 mm in the mountainous regions, and between 1000-2000 mm in lower lying regions (Lee 2015). The combination of rainfall and temperature patterns in Indonesia can lead to impoverished soils, through erosion, weathering, and leaching of nutrients, which drives farmers to clear forests in search of soils suitable for cutivation (Kartasubrata 1993).

Further threats to Indonesia's forests and farmland come from risks associated with increased frequency of extreme events such as droughts, floods, and cyclones, and increases in temperature, prolonged dry seasons, pests and disease, and sea level (along its $81,000 \mathrm{~km}$ of coastline) (GOI 2017; GON 2018). Examples of estimated crop impacts from such threats to food security include decreases in rice production in some parts of the country by 3.6 million tons and young perennial plant die-back of up to $30 \%$ (Sutardi and Hilman 2007; GOI 2017). Given that such threats, and their underlying causes, are similar to those experienced by agroforestry systems in other countries, Indonesia presents a useful case study for analysis of the contribution of agroforestry to smallholder food security.

Agroforestry and the FAO food security pillars

In the 2009 World Summit on Food Security, state leaders signed a declaration acknowledging that the "effects of longstanding underinvestment in food security, agriculture, and rural development have recently been further exacerbated by food, financial and economic crises, among other factors" (FAO 2009). In this same statement they reconfirmed the importance of the FAO pillars, noting that ensuring availability, accessibility, utilization, and stability is the best means of both "reversing this trend" and "progressive realization of the right to adequate [...] food security" (FAO 2008). Since that time, the FAO and the broader agroforestry community have underlined how agroforestry supports the pillars, where biodiversity of agroforestry systems can support environmental stability and allow for greater food access, income generation, and improved health (Maradiaga 2015; Jemal and Callo-Concha 2017; concepts presented in relation to the pillars à la
Gillespie et al. (2012), Weingartner (2004), and Jamnadass et al. (2015) in Fig. 1).

The potential for agroforestry to contribute to food security is context-dependent, with many agroforestry contributions to food security arising both directly and indirectly, complicating definitive categorization (Sanchez 1999; Dwivedi et al. 2013; Ray et al. 2013; Wheeler and van Braun 2013 Challinor et al. 2014). Hence, the categorizations used here are presented in a simplified manner (Rahman et al. 2016b). For example, many of the agroforestry benefits associated with "health" and "income" could equally be considered to support both the "utilization" and "accessibility" pillars, which along with the "availability" on which they depend, are noted as being reliant upon the "stability" pillar (Weingartner 2004).

The FAO (2015) defines stability as when "food, income and economic resources at the household level remain constant, as well as minimization of external risks such as natural disaster and climate change..." Agroforestry can enable a more stable environment for food security through ecosystem resilience and services brought by the functional diversity and species interactions of its inherent biodiversity. Such ecosystem services can include microclimate regulation, attraction of pollinators and pest-predators, soil amelioration, protection of watersheds, and reduction of disease impacts (Garrity 2004; Zhang et al. 2007; Jamnadass et al. 2015; Rosenstock et al. 2016). Such benefits can be conferred through provision of shade by branches and transpiration by leaves, habitat creation, mediation of soil moisture levels, as well as minimizing soil erosion and runoff by deep root systems; and increased soil fertility through leaf litter decomposition (Garrity 2004; Bedimo et al. 2008; Jose 2009; Mitchell et al. 2014). Many such benefits combine to reduce plant stress and maintain longerterm environmental stability through enhanced carbon capture (contributing to climate change mitigation) and potential reduction of dependence on agricultural inputs (e.g. inorganic fertilizers, herbicides, and pesticides) (Nair 1993; Jose 2009; Nair et al. 2010; Nair and Toth 2016; Waldron et al. 2017). The primary advantage of such stability is to increase the quality and quantity (both in terms of volume and variety) of system outputs, contributing to food access, or what the FAO (2015) defines as food availability (i.e. "the physical existence of food"). 


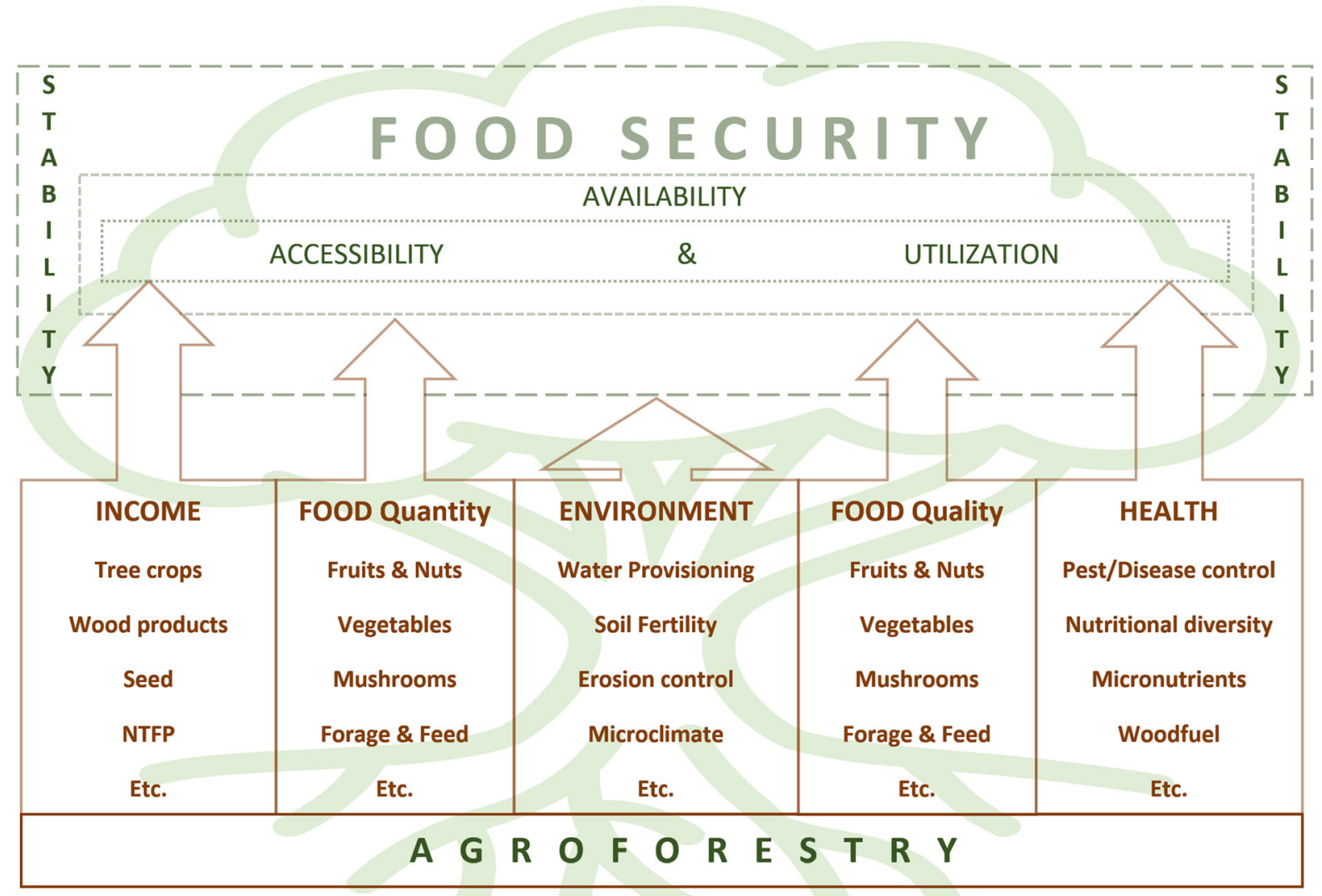

Fig. 1 Simplified diagram of agroforestry pathways for food security

The availability of higher qualities and quantities of outputs from agroforestry systems can support the other two pillars. The FAO (2015) defines food utilization as the requisite "healthy physical environment", "knowledge and habits, including storage,..." and "ability of the human body to take food and convert it into $[. .$.$] energy..." and food accessibility as$ "when all households have enough resources to obtain food in sufficient quantity, quality and diversity for a nutritious diet." In addition to the aforementioned environmental benefits, agroforestry has the potential to increase utilization through contributions to income, nutrition and health status as some agroforestry outputs can have biomedical attributes, while others constitute commodities [such as nuts, coffee, cacao, fuelwood, and other non-timber forest products ("NTFP")] that can be sold, stored for long periods, and/or utilized in food preparation (Rao et al. 2004; Roshetko et al. 2008; Jamnadass et al. 2015). For example, agroforestry fuelwood lots can reduce labor demands associated with fuelwood collection, while producing woods with high energy content and low smoke emissions, utilizable for cleaner cooking, heating, construction, and sale (Tabuti et al. 2003; Toth et al. 2017b). The health aspect of accessibility similarly can benefit from agroforestry's contributions to dietary diversity through, for example, introduction of new fruit and vegetable species, cultivation of animal fodder for livestock systems (providing more milk and other livestock-derived products), or the income generation allowing for purchase of more diverse types of food and medicine (Jamnadass et al. 2013, 2015; Roshetko et al. 2013; Toth et al. 2017a).

Despite its potential beneficial effects on food security and provision of ecosystem services, agroforestry can also have negative impacts, which can occur where projects are poorly designed or where their implementation is interrupted or incomplete. Other negative effects that can potentially occur from agroforestry systems can be to change the dynamics of 
zoonotic diseases, particularly where disease agents are transmitted by animals or insects whose frequency of interaction with humans is altered through agroforestry systems. Because of the potential for negative effects, it is important that agroforestry schemes are well designed. To determine the state of our understanding of agroforestry programs in the case study of Indonesia, and to identify the knowledge gaps that might hinder its effectiveness as a tool for strengthening food security, we performed a structured review of the published literature on Indonesian agroforestry schemes over the past decade (2009-2019).

\section{Methodology}

To systematically examine the literature on agroforestry and food security in Indonesia, we employed the "standard review" guidelines outlined in the PRIS soil fertility MA statement (Liberati et al. 2009). First, the criteria for inclusion were defined, followed by systematic implementation of defined search strings across three databases (Web of Science, Scopus, and PubMed). Search terms that produced duplicate results without identifying additional studies were eliminated in subsequent iterations. Once the qualifying studies were collected, the relevant data was extracted and qualitatively synthesized.

\section{Inclusion criteria}

Peer reviewed articles were included in the analysis based on the criteria listed in Table 1. Only articles published in English were included. In addition, to keep the review as current as possible, only articles published between 2000 and 2019 were included. To enable higher quality, grey literature and other nonpeer reviewed pieces were also excluded. Other inclusion criteria were: (1) Geographic Location (2) Primary Data, (3) Smallholders or Households, (4) Agroforestry and Food Security, and (5) Measurable Food Security Aspects. Essentially, the study must have involved Indonesia, analyzed primary data, and focused on smallholder farmers (Table 1) or their households, while examining agroforestry in the context of some measurable aspect of food security (based on the relationships defined above: food access, nutritional status, dietary diversity, or income).
Development of search strings

The search terms related to agroforestry, food security, and Indonesia are outlined in Table 2 (additional search terms relating to specific practices or to the FAO food security pillars were also considered, but not pursued as they did not yield any additional results). Potentially relevant studies were imported into EndNote (version X8). The study titles were then screened for duplicates. Following the removal of duplicates, the titles and abstracts were reviewed, and inclusion criteria applied. The remaining titles were reviewed in full and data therefrom was included in the analysis. In addition, bibliographies of the included articles were reviewed for potentially relevant sources. Any such sources were then included for full text review. Those that met the inclusion criteria were also included in the analysis.

\section{Study selection}

Figure 2 elucidates the steps of the systematic review process. Initial searches utilizing the search strings for agroforestry, food security, and Indonesia (Table 2) returned 607 records from the included databases. A total of 108 duplicates were removed leaving 499 titles to be screened. Applying the inclusion criteria (Table 1) resulted in the exclusion of a further 365 titles. The abstracts of the remaining 134 articles were then assessed based on the same criteria. This resulted in the exclusion of a further 103 articles, leaving 31 articles for full text review.

After reviewing the qualifying articles, their bibliographies were examined for potentially relevant papers. This returned a further 21 articles for review. Of the 52 articles reviewed (31 from full text review and a further 21 identified in the bibliographies of those articles), a total of 30 articles were excluded. Eight articles did not meet peer review criteria, one article was not related to smallholders or their households, while a further 12 articles did not have sufficient focus on agroforestry, food security, or Indonesia. Two more articles focused on natural and plantation forests, to the exclusion of agroforestry. Lastly, seven articles were either inaccessible or were not published in English (leading to a limitation in this review methodology), leaving a total of 22 qualified studies (hereinafter "studies"). (Further details regarding the criteria and study methods related to 
Table 1 Inclusion criteria for systematic review

\begin{tabular}{ll}
\hline Category & Inclusion details \\
\hline Language & Non-English studies have been excluded \\
Publication date & Any studies prior to 2000 have been excluded \\
Peer reviewed & Only peer reviewed articles have been included \\
Geography & Studies related to Indonesia \\
Primary data & Studies must present primary data \\
Subjects & Studies must relate to smallholder farmers \\
Treatment & Studies must relate to agroforestry generally, or one of its practices or pseudonyms, such as homegardens, \\
& intercropping, silvopasture, forest farming, intercropping, alley cropping, riparian buffers, live fence, mixed \\
farming, evergreen agriculture, or windbreaks \\
Food security & Studies must relate to one or more aspect of Food Security, such as: \\
aspect & $\bullet$ Food Access (quantity/quality) \\
& $\bullet$ Nutritional Status \\
& $\bullet$ Dietary Diversity
\end{tabular}

food security can be found in Supplementary Table 1 in the Additional Resources section.)

\section{Data}

Figure 3 utilizes data from the World Food Program ("WFP") Food Security and Vulnerability Atlas to highlight food security vulnerability levels in different regions of Indonesia; regions are classified into six priority groups, with groups one and two being the most vulnerable, groups three and four being moderately vulnerable, and groups five and six classed as relatively food secure (WFP 2015). Each study is listed in Table 3 along with the vulnerability level of its location and its noted agroforestry system(s) and food security aspects. Figure 3 and Table 3 highlight that most of the agroforestry studies (over 86\%) fell between WFP vulnerability levels two and six, as they were conducted in either Sumatra or Java. Studies involving agroforestry practices requiring larger land areas, such as those focused on specific tree-based systems, were generally located in Sumatra, and second in number only to studies involving homegardens, all of which took place in Java (for greater insight into homegardens in the Indonesian context, see Roshetko et al. 2002). The food security focus of the studies was also skewed, with income and food access being the first and second most investigated aspects. Few studies explicitly considered dietary diversity or nutritional status.

\section{Results}

None of the 22 peer-reviewed studies on agroforestry explicitly attempted to measure the FAO definition of food security. However, the studies did analyze some agroforestry benefits relating to food security, in particular food access, dietary diversity, nutrition security, and income. While some of the studies examined only one such element, others examined a number of the elements. About $50 \%$ of the studies investigated elements related to food access, while $80 \%$ examined elements related to income. About $36 \%$ investigated elements related to dietary diversity, while only $9 \%$ contained elements related to nutritional security.

Food access

Ten of the studies contained elements relating to food availability. However, only one study specifically investigated a primary result of increased food access, i.e. energy intake (Sasaoka et al. 2014). It found that sago produced on Seram Island accounts for $76 \%$ of total energy intake, where the productivity of sago groves was between five and 16 times greater than 
Table 2 Search terms and strings used for systematic review

\begin{tabular}{|c|c|}
\hline $\begin{array}{l}\text { Search } \\
\text { aspect }\end{array}$ & Strings \\
\hline Agroforestry & 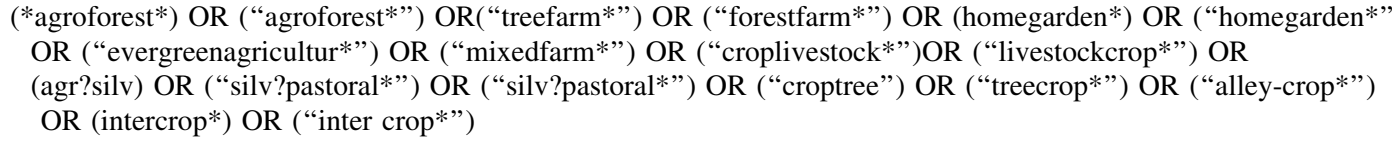 \\
\hline \multicolumn{2}{|l|}{ AND } \\
\hline $\begin{array}{l}\text { Food } \\
\text { Security }\end{array}$ & $\begin{array}{l}\text { (income*) OR (nutrition*) OR ("food security*") OR (diet*) OR ("food suffic*") OR ("food insecur*") } \\
\text { OR ("nutrit* secur*") OR ("nutrit* insecur*") OR ("nutrit* insecur*") OR ("food insuffic*") OR ("hunger*") } \\
\text { OR ("nutrit* suffic*") OR("nutrit* insuffic*") OR ("food") }\end{array}$ \\
\hline \multicolumn{2}{|l|}{ AND } \\
\hline Indonesia & $\begin{array}{l}\text { (indonesia*) OR(java*) OR (sumatra*) OR(sulawesi)OR (kalimantan) OR (papua*) OR (maluku*) OR (sunda*) } \\
\text { OR(guinea*)OR (aceh) OR (riau*) OR(jambi) OR(bengkulu) OR (bangka*) OR (lampung) OR (bali) } \\
\text { OR(nusa* AND banten OR jakarta OR yakartayog*) OR (banten) OR (jakarta) OR (yogyakarta*)) }\end{array}$ \\
\hline
\end{tabular}

upland rice. While they did not directly investigate food availability, a further three studies involving both traditional and commercial homegardens did consider some aspects of food availability (i.e. Abdoellah et al. 2006, Muliawati et al. 2018, and Prihatini et al. 2018). For example, one study found that $27 \%$ of the cultivated components of the investigated homegardens were comprised of subsistence plants (Muliawati et al. 2018).

While the other studies had fewer direct links to food availability, some contained elements of relevance to food access. For example, a study in Sumatra found that poorer farmers that engaged in agroforestry training increased the volume and variety of their crop production (Pratiwi and Suzuki 2019). In addition, two studies reported the use of secondary NTFPs (such as mangosteen, durian, garcinia, candlenut, lanzones, lansium, bitter bean, areca nut, ginger, turmeric, chili, papaya, etlingera, and banana) for subsistence (Belcher et al. 2004; Affandi et al. 2017). A further two studies indicated that the increasing popularity of short-term perennials with high international demand (e.g. cacao, coffee, and pepper) led to a reduction in the planting of staple food crops, potentially lowering direct access to staple foods (Belsky and Siebert 2003; Kusters et al. 2008). Similarly, a study based in Java investigated agroforestry in smallholder agriculture systems and highlighted a short-term reduction in access to subsistence foods, although it was argued that this effect could be mitigated by establishment of fruit trees (Rahman et al. 2016a).

\section{Dietary diversity and nutrition security}

In total, eight of the studies contained elements related to dietary diversity, while two were related to both nutrition security and dietary diversity. Of note, Pratiwi and Suzuki (2019) found that poorer farmers that engaged in agroforestry training increased their levels of crop diversification. However, it is not axiomatic that increased levels of food production or crop diversification in a locality will translate into improved nutritional outcomes for the farmers households or communities. Indeed, Ruel and Alderman (2013) found little evidence of the effectiveness of food production programs on child nutritional status. Relatedly, Ickowitz et al. (2016) utilized spatial data to investigate the intake of micronutrient-rich foods amongst children under five. Their results displayed a correlation at the national level between agroforestry and increased consumption of legumes. At the regional level, the findings highlighted a correlation between agroforestry and increased consumption of Vitamin A rich fruits and green leafy vegetables. In addition, agroforestry systems were also associated with increased meat consumption, in particular those involving silvopastoral aspects (Ickowitz et al. 2016).

One study of the effects of homegardens in Java investigated Vitamin A intake pre- and post-homegarden extension intervention, reporting a modest increase in vegetable consumption, but no increase in Vitamin A intake (Diana et al. 2014). The authors suggested that this may be due to the small size of 


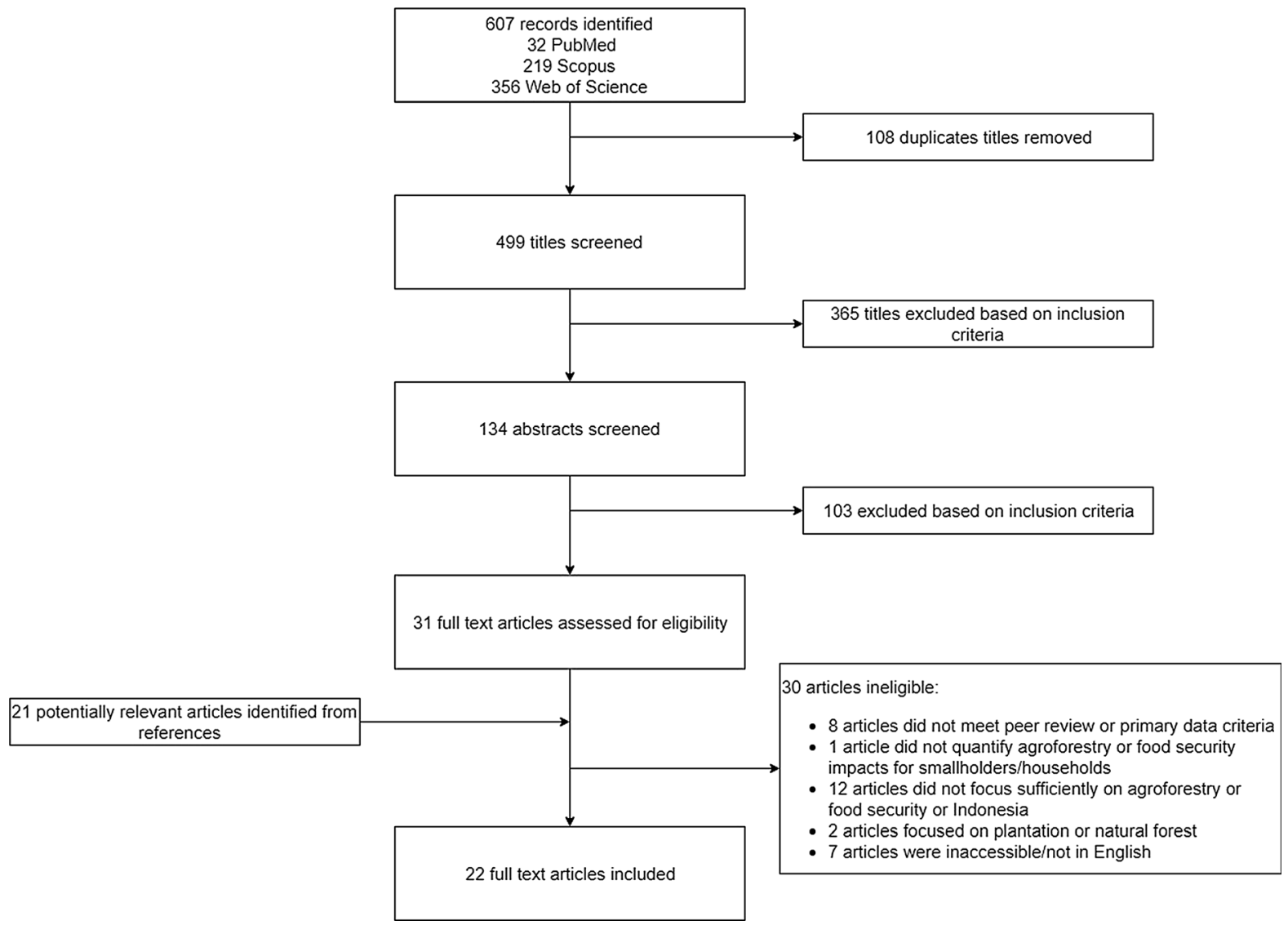

Fig. 2 Flowchart illustrating the systematic review process from identification of 607 recorded documents matching the initial search terms to 22 articles deemed eligible for full analysis

many of the homegardens resulting in insufficient production. Two studies further compared traditional homegardens to commercial homegardens (Abdoellah et al. 2006; Prihatini et al. 2018), with both reporting that species diversity was $20 \%$ greater in traditional homegardens. In addition, one of these studies claimed that traditional homegardens functioned as both "living barns" and "living pharmacies;" noting their importance for dietary and medicinal plant species diversity (Prihatini et al. 2018). Greater dietary diversity resulting from secondary NTFPs, such as honey, fuelwood, and medicinal plants, was also claimed in the context of rattan-based agroforestry (Belcher et al. 2004).

\section{Household income}

A total of 18 studies investigated the impacts of agroforestry on household income. Half of these focused on income alone, while the remainder also considered other categories. The majority of these studies reported agroforestry as a significant contributor to income, with some describing various agroforestry systems as "living savings accounts" (Roshetko et al. 2013; Prihatini et al. 2018). For example, one study of agroforestry in smallholder agriculture systems highlighted general long-term potential income gains (Rahman et al. 2016a), while in other cases this was largely ascribed to the sale of secondary NTFP (Belcher et al. 2004; Affandi et al. 2017). A study of coffee agroforestry systems in Sumatra found that commodity production contributed to over $54 \%$ of household income, compared to a $12.5 \%$ contribution from the traditional agricultural components (Suyanto et al. 2007). A study of damar agroforestry indicated that, on average, it contributed up to $51 \%$ of household income for those that utilized it (Wollenberg and Nawir 2005). In teak agroforestry 


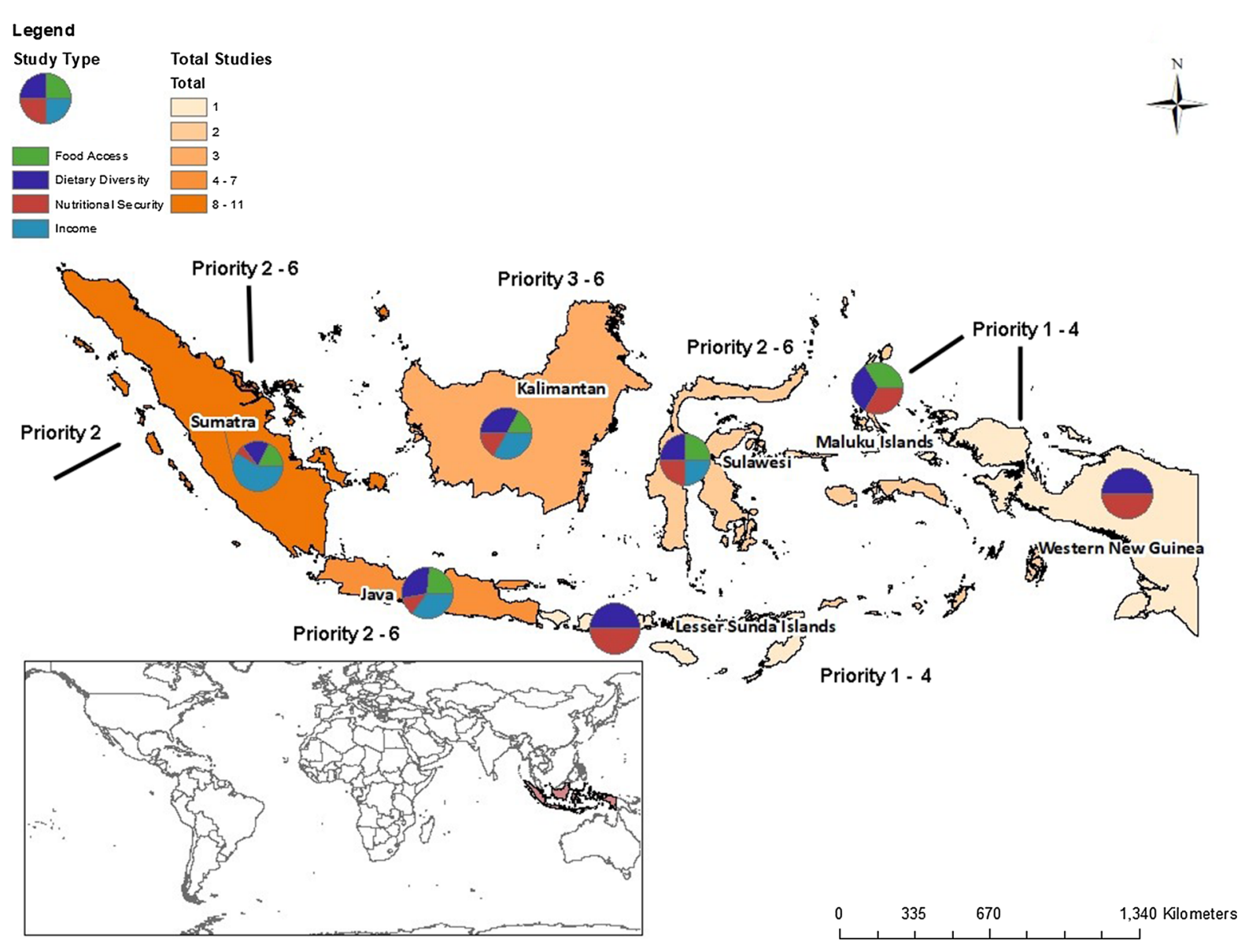

Fig. 3 Major geographic units of Indonesia, indicating World Food Program 2015 Food Security Priority Zones, and Agroforestry Study Site Types. Adapted from WFP (2015)

systems, 12, 25, and $61 \%$ of household income was contributed by the teak component, agricultural production, and off-farm activities, respectively (Roshetko et al. 2013). A hortus study also found that agroforestry allowed for greater off-farm income contributions due to some types of agroforestry being less labor-intensive than traditional local agricultural practices (Rahman et al. 2016b). Finally, two studies compared agroforestry options to traditional options, and found agroforestry to have up to 98 and $65 \%$ greater net present value (for periods in excess of 30 years) compared to (a) slash \& burn and (b) maize or rice production, respectively (Wibawa et al. 2005; Rahman et al. 2017 ).

The studies related to homegardens reported much higher incomes (up to 500\%) for commercial homegardens, than for traditional homegardens, but much lower biodiversity (Abdoellah et al. 2006; Prihatini et al. 2018). However, commercial homegardens required inputs valued at between 35 and $75 \%$ of the value of production. In addition to such costs, poor management practices in certain agroforestry systems were shown to reduce the profitability of such systems. In Java, $43 \%$ of the farmers practiced thinning that removed the most valuable wood before maturity, but teak agroforestry nonetheless remained profitable (Roshetko et al. 2013). In addition, a study of damar agroforestry found that damar resin profitability and productivity declined by 34 and $37 \%$ (between 1995 and 2004), respectively (Kusters et al. 2008). Such reductions were considered to be a result of a reduced harvest interval, which had been, on average, every 4.35 weeks, but was reduced to every 2.98 weeks during the study period. These values were however specific to resin and did not indicate the profitability of the overall farming system. 
Table 3 Peer-reviewed research studies of agroforestry in Indonesia

\begin{tabular}{|c|c|c|c|c|c|}
\hline FSA & System & Species & Area & WFP & References \\
\hline $\begin{array}{c}\mathrm{D} / \mathrm{F} / \\
\mathrm{I}\end{array}$ & Homegarden $(\mathrm{T} / \mathrm{C})$ & $N A$ & Java & $2-6$ & Prihatini et al. (2018) \\
\hline $\begin{array}{c}\mathrm{D} / \mathrm{F} / \\
\mathrm{I}\end{array}$ & $\operatorname{Rattan}(\mathrm{T} / \mathrm{C}) * *$ & Daemonorops & Kalimantan & $3-6$ & Belcher et al. (2004) \\
\hline $\begin{array}{c}\mathrm{D} / \mathrm{F} / \\
\mathrm{I}\end{array}$ & Oil Palm* (T/C) & Elaeis guineensis & Kalimantan & $3-6$ & Belcher et al. (2004) \\
\hline $\begin{array}{c}\mathrm{D} / \mathrm{F} / \\
\mathrm{I}\end{array}$ & Rubber* (T/C) & Hevea brasiliensis & Kalimantan & $3-6$ & Belcher et al. (2004) \\
\hline $\begin{array}{c}\mathrm{D} / \mathrm{F} / \\
\mathrm{I}\end{array}$ & Reba-Juma $(\mathrm{T})^{*}$ & Areca catechu, Garcinia atroviridis & Sumatra & $2-6$ & Affandi et al. (2017) \\
\hline $\begin{array}{c}\mathrm{D} / \mathrm{F} / \\
\mathrm{I}\end{array}$ & Intercropping (T/C) & Caffea arabica, Theobroma cacao & Sumatra & $2-6$ & Pratiwi and Suzuki (2019) \\
\hline $\mathrm{D} / \mathrm{F}$ & Homegardens $(\mathrm{T})$ & Theobroma cacao, Melia azedarach & Java & $2-6$ & Muliawati et al. (2018) \\
\hline $\mathrm{D} / \mathrm{I}$ & Durian \& Teak $(\mathrm{T} / \mathrm{C})^{* *}$ & Durio zibethinus, Tectona grandis & Java & $2-6$ & Rahman et al. (2017) \\
\hline $\mathrm{D} / \mathrm{N}$ & Homegarden $(\mathrm{T})$ & $N A$ & Java & $2-6$ & Diana et al. (2014) \\
\hline $\mathrm{D} / \mathrm{N}$ & Teak $(\mathrm{C}) * *$ & T. grandis, Acacia mangium & Java & $2-6$ & Ickowitz et al. (2016) \\
\hline $\mathrm{D} / \mathrm{N}$ & $\begin{array}{l}\text { Swidden/Improved Fallows } \\
\text { (T) }\end{array}$ & $N A$ & Kalimantan & $3-6$ & Ickowitz et al. (2016) \\
\hline $\mathrm{D} / \mathrm{N}$ & Mix Gardens $(\mathrm{C})^{*}$ & H. brasiliensis, C. arabica & Sumatra & $2-6$ & Ickowitz et al. (2016) \\
\hline $\mathrm{D} / \mathrm{N}$ & $\begin{array}{l}\text { Swidden/Improved Fallows } \\
\text { (T) }\end{array}$ & $N A$ & Sulawesi & $2-6$ & Ickowitz et al. (2016) \\
\hline $\mathrm{F} / \mathrm{I}$ & Homegarden $(\mathrm{T} / \mathrm{C})$ & Allium fistulosum & Java & $2-6$ & Abdoellah et al. (2006) \\
\hline $\mathrm{F} / \mathrm{I}$ & Durian \& Teak $(N A)^{* *}$ & D. zibethinus, T. grandis & Java & $2-6$ & Rahman et al. (2016a) \\
\hline $\mathrm{F} / \mathrm{I}$ & Cacao $(\mathrm{C})^{*}$ & T. cacao & Sulawesi & $2-6$ & Belsky and Siebert (2003) \\
\hline $\mathrm{F} / \mathrm{I}$ & $\operatorname{Damar}(\mathrm{C})^{*}$ & Shorea javanica & Sumatra & $2-6$ & Kusters et al. (2008) \\
\hline $\mathrm{F}$ & Sago-vegeculture (T) & Metroxylon sagu & $\begin{array}{l}\text { Maluku } \\
\text { Isls }\end{array}$ & $1-4$ & Sasaoka et al. (2014) \\
\hline I & Homegarden $(\mathrm{T})$ & $\begin{array}{l}\text { Nephelium lappaceum, Anthocephalus } \\
\text { cadamba }\end{array}$ & Java & $2-6$ & Rahman et al. (2016b) \\
\hline I & Mix Gardens (T/C) & T. grandis, Phyllanthus acidus & Java & $2-6$ & Rahman et al. (2016b) \\
\hline I & Teak $(\mathrm{C}) * *$ & T. grandis & Java & $2-6$ & Roshetko et al. (2013) \\
\hline I & Rubber $(\mathrm{T} / \mathrm{C})^{*}$ & Hevea brasiliensis & Kalimantan & $3-6$ & Rist et al. (2010) \\
\hline I & Rubber $(\mathrm{C})^{*}$ & Hevea brasiliensis & Sumatra & $2-6$ & Rist et al. (2010) \\
\hline I & Coffee $(\mathrm{T} / \mathrm{C})^{*}$ & C. arabica & Sumatra & $2-6$ & Suyanto et al. (2007) \\
\hline I & Damar $(\mathrm{T} / \mathrm{C})^{*}$ & Shorea javanica & Sumatra & $2-6$ & $\begin{array}{l}\text { Wollenberg and Nawir } \\
\text { (2005) }\end{array}$ \\
\hline I & Jernang $(\mathrm{C})^{*}$ & Daemonorops draco & Sumatra & $2-6$ & Widianingsih et al. (2019) \\
\hline I & Mix Gardens (T) & H. brasiliensis, C. arabica & Sumatra & $2-6$ & $\begin{array}{l}\text { Murniati and Gintings } \\
\text { (2001) }\end{array}$ \\
\hline I & Rubber $(\mathrm{T} / \mathrm{C})^{*}$ & H. brasiliensis & Sumatra & $2-6$ & Wibawa et al. (2005) \\
\hline I & Sisipan $(\mathrm{T} / \mathrm{C})^{*}$ & H. brasiliensis & Sumatra & $2-6$ & $\begin{array}{l}\text { Lehébel-Péron et al. } \\
\text { (2011) }\end{array}$ \\
\hline
\end{tabular}

FSA Food Security Attribute, $C$ Commercial, $T$ Traditional, $F$ Food access, $D$ Dietary diversity, $N$ Nutrition security, $I$ Income, $*$ NTFP focused Agri-silviculture, ** Timber focused Agri-silviculture 
Additional food security benefits

Many of the agroforestry studies reported additional indirect food security benefits, which could strengthen stability and resilience. The establishment of trees was argued to confer land tenure security in studies spanning rattan gardens, durian and teak agroforestry systems, and cacao (Belsky and Siebert 2003; Belcher et al. 2004; Rahman et al. 2017). Environmental benefits were reported in a range of studies. For example, several studies reported that those engaged in agroforestry practices were less reliant on natural forests for fuelwood, food, and other resources. It was also reported that agroforestry farmers collected $83 \%$ less firewood and $65 \%$ less food from natural forests, relative to rice and maize farmers (Rahman et al. 2017). One study of coffee systems reported that engagement of local farmers in conservation efforts increased positive outcomes, such as incomes, equitable distribution of land holdings, and rehabilitation of degraded lands, leading to greater social stability (Suyanto et al. 2007). Several studies also highlighted "risk reduction" (specifically concerning lack of food from crop failure and income volatility) as an outcome of greater diversification through agroforestry (Belcher et al. 2004; Pratiwi and Suzuki 2019).

In addition to increases in profitability, stability of income can also be a key benefit for households. In a study of damar agroforestry, it was claimed that farmers valued the year-round availability of damar resin and the stabilizing effect on supply and prices (Wollenberg and Nawir 2005). Pratiwi and Suzuki (2019) also reported reduced income fluctuations amongst poorer smallholders adopting agroforestry techniques. Furthermore, Wibawa et al.'s (2005) comparison of a slash \& burn cyclical system and a sisipan agroforestry system (involving the planting of young rubber trees between well-established ones) found that $99 \%$ of the respondents considered that the sisipan system allows for greater continuity in revenue streams.

\section{Discussion}

In this study, we have systematically reviewed studies of agroforestry schemes across Indonesia from all available literature. We consider (a) to what extent previous research has clarified knowledge gaps within the field and which gaps remain; (b) the applicability of our approach for other countries in South-east Asia and throughout the global tropics; and (c) how ongoing limitations of our understanding of the contributions of agroforestry to food security can be addressed.

Homegardens make direct and indirect contributions to food security but remain understudied outside of Java

Taken together, there are a number of significant findings from the six homegarden studies. While commercial homegardens throughout the region indirectly increase food availability and utilization through income generation, the outputs are recognized as less diverse than traditional homegardens. While this suggests that traditional homegardens may be more successful at providing direct dietary diversity and nutritional security, it does not provide conclusive evidence as to which types of homegardens provides greater overall nutritional benefits. Indeed, higher income may provide for greater resilience in the face of environmental shocks, such as floods or droughts, as noted by a study in Vietnam, while traditional homegardens' allowance for exposure to a wider variety of vegetables on a more regular basis may better protect individuals from health shocks, such as undernutrition related maladies (Suthari and Prasad 2016; Duffy et al. 2020). There is a need for further studies to determine whether (and how) dietary diversity and nutritional outcomes associated with commercial versus traditional homegardens differ, particularly when faced with the impacts of climate change. Moreover, there is a lack of homegarden studies outside of Java, indicating a geographic gap in the research, including in areas which are less accessible and therefore possibly more food-insecure.

It would be desirable if food security studies on agroforestry systems included some analyses of indirect benefit measures, such as the environmental and social impacts of homegardens. While some of the studies considered impacts on labor arising from the agroforestry systems, it is not clear whether (or how) any labor-saving gains (or losses) from agroforestry systems impact on food security outcomes in Indonesia. However, there are some studies that explore possible relationships. For example, Roshetko et al. (2008) and Sabastian et al. (2014) suggest that off- 
farm employment can result in increases in the use or management of tree-farming systems, given the somewhat seasonal nature of such systems and offfarm labor demands. Kumar et al. (2018), based on their work in Zambia, cautioned against agricultural program interventions that could encourage increases in time spent farming, when this may not be in a household's best interest. Given that the scaling out of practices such as agroforestry have been found to be constrained by labor availability in places such as Malawi (Murray et al. 2016; Toth et al. 2019), further studies are necessary to better understanding how labor (and gender roles) may affect scaling out and food security outcomes of agroforestry systems in Indonesia. It appears that most of the studies in Indonesia to date typically focus on the income aspect of utilization in relation to the FAO definition of food security.

Agri-silviculture systems focused on non-timber forest products make intermediate outcome contributions to food security

Nine of the studies, all based in Sumatra, focused on different types of large tree-based agroforestry systems producing NTFPs. Within these studies, food access, dietary diversity, and income all featured prominently. Similar to the studies involving homegardens, distinctions were made between those systems leaning toward commercial purposes and those more focused on subsistence, with many falling somewhere in-between (i.e. having varying degrees of emphasis on both). However, even those studies focused on subsistence indicated that the agroforestry systems provided substantial income contributions. While these studies did incorporate more than one food security aspect, the limited geographic scope of this body of research represents a key gap. The studies suggest that agroforestry system designs need to carefully balance income and subsistence requirements, taking into account what can be purchased in local markets and what needs to be produced by the household, to better meet dietary diversity and food access needs. Again, such a balance is context dependent, as identified by Singh (2018) in India, where he found income diversification acts as a "protective shield" for smallholder farmers, but those transitioning to an income focused system rely on the subsistence and environmental supports of such systems until the commercial component become sustainable. Future agroforestry and food security studies need to be aware that nutrition-sensitive agricultural interventions targeted at vulnerable populations can improve transitional and intermediate outcomes such as dietary diversity. However, it must be recognized that there is currently limited evidence that such nutrition sensitive agricultural interventions improve long-term nutritional and health outcomes, such as child growth (Gillespie et al. 2012; Bird et al. 2019). Agroforestry and food security studies in Indonesia are needed which move beyond intermediate outcomes to assessing longer term impacts on health and nutrition.

Agri-silviculture systems focused on timber increased income but had unclear impacts on food security outcomes

Similar to commercial homegardens, agri-silviculture systems that are predominantly focused on timber typically had lower levels of dietary diversity, yet higher income levels. Most such studies on agrisilviculture systems involved financial analyses. In such analyses, management effects on profitability were easier to identify than in other more complex agroforestry systems. Such timber-focused systems were not necessarily lacking in other elements, as the diversity considerations work on different timescales. For example, silvopastoral and environmental benefits were certainly identified in such studies, as was the ability to earn greater off-farm income due to the lower maintenance and long cycles of such systems. Future research on timber focused agri-silviculture systems should consider greater integration of food security factors and outcomes into financial analyses.

Food security impacts from broader agroforestry practices and systems in Indonesia

The remaining agroforestry studies concerned more widely applicable agroforestry practices or systems for smallholder farmers, such as intercropping, improved fallows/swidden, or sago-based systems. These studies were diverse in locality and analysis and the results were generally favorable in relation to food security. As with other agroforestry systems throughout Asia (e.g. Satoyama landscapes; Ichikawa and Toth 2012), and as noted in the results, the benefits to food security 
in Indonesia were recognizable, particularly with regard to dietary diversity and the stabilizing effects of both environmental and income benefits.

\section{Conclusions}

This systematic review of research concerning agroforestry contributions to the FAO food security pillars in Indonesia identified several trends as well as significant knowledge gaps. Although these knowledge gaps included a lack of studies carried out in areas other than Sumatra and Java, we note that our search criteria tended to favor the language used to describe agroforestry and food security in research studies from other countries within the region, so it should not be assumed that agroforestry and food security have not been investigated elsewhere. Nevertheless, and considering the lower levels of food security identified by the World Food Program in areas such as Papua and Maluku, more studies connecting agroforestry systems to food security are clearly needed outside of Java and Sumatra to determine their potential roles in WFP's food security priority zones. Our methodology could also be useful for similar analyses in other parts of Southeast Asia to facilitate comparisons across agroecological zones. Our findings indicate that both commercial and traditional homegardens contribute to food security in Java, primarily through income from the prior and dietary diversity from the latter. A similar "twin track" exists for food security contributions from agri-silviculture practices based on a timber versus non-timber forest product divide, suggesting more general applicability across Indonesia and the wider region. Notably, agroforestry systems with a timber or commercial focus tended to favor income production, while those focused on traditional and non-timber products favored dietary diversity benefits. In both groups, nearly all studies suggested that agroforestry systems contribute to stability through environmental benefits which were however rarely quantified. Moreover, while many of the identified studies focus on income in a food security context, those addressing traditional agroforestry systems often lacked rigorous financial analyses. Household capture of off-farm income, made possible by the use of agroforestry systems, may have a more positive influence on nutritional outcomes than increased crop diversity, if such income enhances household capacity to purchase nutritious foods via market processes. Finally, as Indonesia undergoes further urbanization the differing roles of homegardens and other agroforestry practices in rural (as opposed to urban or peri-urban) areas will need to be systematically addressed. Our review indicates that such a possibility has not yet been systematically investigated across agroforestry systems in Indonesia and represents a knowledge gap. Furthermore, more varied forms of agroforestry (such as intercropping and improved fallows) should also be further investigated throughout Indonesia with a more explicit focus on food security, in relation to current and future climate challenges.

Acknowledgements The authors confirm that this study has not been published previously, that it is not under consideration for publication elsewhere, that its publication is approved by all authors and tacitly or explicitly by the responsible authorities where the work was carried out, and that, if accepted, it will not be published elsewhere in the same form, in English or in any other language, including electronically without the written consent of the copyright-holder.

Funding Open Access funding provided by the IReL Consortium. Open Access funding provided by the IReL Consortium. The Authors acknowledge funding support from the Irish Research Council Postgraduate Scholarship scheme (Grant no GOIPG/2015/3416). The authors are thankful to two reviewers of an earlier draft of the manuscript for their helpful comments and advice.

\section{Declaration}

Conflict of interest The authors declare that they have no conflict of interest.

Open Access This article is licensed under a Creative Commons Attribution 4.0 International License, which permits use, sharing, adaptation, distribution and reproduction in any medium or format, as long as you give appropriate credit to the original author(s) and the source, provide a link to the Creative Commons licence, and indicate if changes were made. The images or other third party material in this article are included in the article's Creative Commons licence, unless indicated otherwise in a credit line to the material. If material is not included in the article's Creative Commons licence and your intended use is not permitted by statutory regulation or exceeds the permitted use, you will need to obtain permission directly from the copyright holder. To view a copy of this licence, visit http://creativecommons.org/licenses/by/4.0/. 


\section{References}

Abdoellah OS, Hadikusumah HY, Takeuchi K, Okubo S, Parikesit (2006) Commercialization of homegardens in an Indonesian village: vegetation composition and functional changes. In: Kumar BM, Nair PKR (eds) Tropical homegardens: a time-tested example of sustainable agroforestry. Springer, Dordrecht, pp 233-250

Affandi O, Zaitunah A, Batubara R (2017) Potential economic and development prospects of non timber forest products in community agroforestry land around Sibolangit tourism park. For Soc 1:68-77

Bedimo JM, Njiayouom I, Bieysse D, Nkeng MN, Cilas C, Notteghem JL (2008) Effect of shade on Arabica coffee berry disease development: toward an agroforestry system to reduce disease impact. Phytopathology 98:1320-1325

Belcher B, Imang N, Achdiawan R (2004) Rattan, rubber, or oil palm: cultural and financial considerations for farmers in Kalimantan. Econ Bot 58:77-87

Belsky JM, Siebert SF (2003) Cultivating cacao: implications of sun-grown cacao on local food security and environmental sustainability. Agr Hum Val 20:277-285

Bird FA, Pradhan A, Bhavani RV, Dangour AD (2019) Interventions in agriculture for nutrition outcomes: a systematic review focused on South Asia. Food Policy 82:39-49

Brown ME, Funk CC (2008) Food security under climate change. Science 319:580-581

Challinor AJ, Watson J, Lobell DB, Howden SM, Smith DR, Chhetri N (2014) A meta-analysis of crop yield under climate change and adaptation. Nat Clim Chang 4:287-291

Diana R, Khomsan A, Sukandar D, Riyadi H (2014) Nutrition extension and homegarden intervention in Posyandu: impact on nutrition knowledge, vegetable consumption and intake of vitamin A. Pak J Nutr 13:88-92

Duffy C, Pede V, Toth GG, Kilcline K, O’Donoghue C, Ryan M, Spillane C (2020) Drivers of household and agricultural adaptation to climate change in Vietnam. Clim Dev 1-14

Dwivedi SL, Sahrawat K, Upadhyaya H, Oritz R (2013) Food, nutrition, and agrobiodiversity under global climate change. Adv Agron 120:1-128

FAO (1996) Rome declaration on world food security and world food summit plan of action. Food and Agriculture Organization, World Food Summit, Rome

FAO (2008) Integrated food security phase classification. Food \& Agriculture Organization, Rome

FAO (2009) Draft declaration of world summit on food security. Food \& Agriculture Organization, Rome

FAO (2015) FAO statistical pocketbook 2015. Food and Agriculture Organization, Rome

FAO, Goi (2017) Country programming framework (2016-2020). Food \& Agriculture Organization, Jakarta

Garrity DP (2004) Agroforestry and achievement of the millennium development goals. Agrofor Syst 61:5-17

Gillespie S, Harris J, Kadiyala S (2012) The agriculture-nutrition disconnect in India: what do we know? IFPRI discussion paper 01187. International Food Policy Research Institute, Washington DC

GOI (2017) Indonesia: third national communication under the united nations framework convention on climate change. Government of Indonesia, Indonesia
GON (2018) Climate change profile: Indonesia. Ministry of Foreign Affairs, Government of the Netherlands, The Hague

Lee HS (2015) General rainfall patterns in Indonesia and the potential impacts of local seas on rainfall intensity. Water 7:1751-1768

Ichikawa K, Toth GG (2012) The satoyama landscape of Japan: the future of an indigenous agricultural system in an industrialized society. In: Nair PKR, Garrity D (eds) Agroforestry - the future of global land use. Advances in agroforestry, vol 9. Springer, Dordrecht, pp 341-358

Ickowitz A, Rowland D, Powell B, Salim MA, Sunderland T (2016) Forests, trees, and micronutrient-rich food consumption in Indonesia. PLoS ONE 11:1-15

ILO (2017) Indonesia country profile. International Labour Organisation, Geneva

Jemal O, Callo-Concha D (2017) Potential of agroforestry for food and nutrition security of small-scale farming households. ZEF Center for Development Research, Bonn

Jamnadass R, McMullin S, Iiyama M, Dawson I, Powell B, Termote C, Ickowitz A, Kehlenbeck K, Vinceti B, Van Vliet N (2015) Understanding the roles of forests and treebased systems in food provision. In: Vira B, Wildburger C, Mansourian S (eds) Forests and food: addressing hunger and nutrition across sustainable landscapes. Open Book Publishers, Cambridge, pp 29-72

Jamnadass R, Place F, Torquebiau E, Malézieux E, Liyama M, Sileshi G, Kehlenbeck K, Masters E, McMullin S, Dawson I (2013) Agroforestry, food and nutritional securityICRAF working paper, 170. World Agroforestry Centre, Nairobi

Jose S (2009) Agroforestry for ecosystem services and environmental benefits: an overview. Agrofor Syst 76:1-10

Kartasubrata J (1993) Indonesia. In: National Research Council (eds) Sustainable agriculture and the environment in the humid tropics. National Academic Press, Washington, DC

Kumar N, Nguyen PH, Harris J, Harvey D, Rawat R, Ruel MT (2018) What it takes: evidence from a nutrition and gender sensitive agriculture intervention in rural Zambia. J Dev Effect 10:341-172

Kusters K, Ruiz Perez M, de Foresta H, Dietz T, Ros-Tonen M, Belcher B, Manalu P, Nawir A, Wollenberg E (2008) Will agroforests vanish? The case of damar agroforests in Indonesia. Hum Ecol 36:357-370

Lehébel-Péron A, Feintrenie L, Levang P (2011) Rubber agroforests' profitability, the importance of secondary products. For Trees Livelihood 20:69-84

Liberati A, Altman DG, Tetzlaff J, Mulrow C, Gøtzsche PC, Ioannidis JP, Clarke M, Devereaux PJ, Kleijnen J, Moher D (2009) The PRISMA statement for reporting systematic reviews and meta-analyses of studies that evaluate health care interventions: explanation and elaboration. Br Med J 339-368

Lobell DB, Burke MB, Tebaldi C, Mastrandrea MD, Falcon WP, Naylor RL (2008) Prioritizing climate change adaptation needs for food security in 2030. Sci 319:607-610

Maradiaga J (2015) Agroforestry system kuxur rum enhancing food and nutritional security in Guatemala. In: Kumar C, Begeladze S, Calmon M, Saint-Laurent C (eds) Enhancing food security through forest landscape restoration: Lessons 
from Burkina Faso, Brazil, Guatemala, Viet Nam, Ghana, Ethiopia and Philippines. IUCN, Gland, pp 70-105

Mertz O, Halsnæs K, Olesen JE, Rasmussen K (2009) Adaptation to climate change in developing countries. J Environ Manag 43:743-752

Mitchell MG, Bennett EM, Gonzalez A (2014) forest fragments modulate the provision of multiple ecosystem services. J Appl Ecol 51:909-918

Muliawati ES, Budiastuti MTS, Suprayogo D, Sutrisno J (2018) Agrobiodiversity in rural homegardens as food reserves for climate change adaptation (case study: Samin SubWatershed, Central Java, Indonesia). Bulg J Agric Sci 24:759-767

Murniati GDP, Gintings AN (2001) The contribution of agroforestry systems to reducing farmers' dependence on the resources of adjacent national parks: a case study from Sumatra, Indonesia. Agrofor Syst 52:171-184

Murray U, Gebremedhin Z, Brychkova G, Spillane C (2016) Smallholder farmers and climate smart agriculture: technology and labor-productivity constraints amongst women smallholders in Malawi. Gend Technol Dev 20:117-148

Nair PKR (1993) An introduction to agroforestry. Kluwer Academic Publishers, Dordrecht

Nair PKR, Toth GG (2016) Measuring agricultural sustainability in agroforestry systems. In: Lal R, Kraybill D, Hansen D, Singh B, Mosogoya T, Eik L (eds) Climate change and multi-dimensional sustainability in African agriculture. Springer, Cham, pp 365-394

Nair PKR, Nair V, Kumar B, Showalter J (2010) Carbon sequestration in agroforestry systems. In: Sparks D (ed) Advances in agronomy 108. Elsevier, Amsterdam, pp 237-307

Pratiwi A, Suzuki A (2019) Reducing agricultural income vulnerabilities through agroforestry training: evidence from a randomised field experiment in Indonesia. Bull Indones Econ Stud 55:83-116

Prihatini J, Iskandar J, Partasasmita R, Nurjaman D (2018) the impacts of traditional homegarden conversion into the commercial one: A case study in Sukapura village of the Upstream Citarum Watershed, West Java, Indonesia. Biodiversitas 19:1926-1940

Rahman SA, Jacobsen JB, Healey JR, Roshetko JM, Sunderland T (2017) Finding alternatives to Swidden agriculture: does agroforestry improve livelihood options and reduce pressure on existing Forest? Agrofor Syst 91:185-199

Rahman SA, Sunderland T, Kshatriya M, Roshetko JM, Pagella T, Healey JR (2016a) Towards productive landscapes: trade-offs in tree-cover and income across a matrix of smallholder agricultural land-use systems. Land Use Policy 58:152-164

Rahman SA, Sunderland T, Roshetko JM, Basuki I, Healey JR (2016b) Tree culture of smallholder farmers practicing agroforestry in Gunung Salak Valley, West Java, Indonesia. Small-Scale For 15:433-442

Rao MR, Palada MC, Becker BN (2004) Medicinal and aromatic plants in agroforestry systems. In: Nair PKR, Rao MR, Buck LE (eds) New vistas in agroforestry: a compendium for 1st world congress of agroforestry. Springer, Dordrecht, pp 107-122
Ray DK, Mueller ND, West PC, Foley JA (2013) Yield trends are insufficient to double global crop production by 2050 . PLoS ONE 8:66-74

Rist L, Feintrenie L, Levang P (2010) Livelihood impacts of oil palm: smallholders in Indonesia. Biodivers Conserv 19:1009-1024

Rosenstock TS, Lamanna C, Chesterman S, Bell P, Arslan A, Richards M, Rioux J, Akinleye AO, Champalle C, Cheng Z, Corner-Dolloff C, Dohn J, English W, Eyrich AS, Girvetz EH, Kerr A, Lizarazo M, Madalinska A, McFatridge S, Morris KS, Namoi N, Poultouchidou N, Ravina da Silva M, Rayess S, Ström H, Tully KL, Zhou W (2016) The scientific basis of climate-smart agriculture: a systematic review protocol. In: Climate change, agriculture and food security working paper 138 . CGIAR, Copenhagen

Roshetko JM, Delaney M, Hairiah K, Purnomosidhi P (2002) Carbon stocks in Indonesian homegarden systems: can smallholder systems be targeted for increased carbon storage? Am J Altern Agr 17:138-148

Roshetko JM, Rohadi D, Perdana A, Sabastian G, Nuryartono N, Pramono AA, Widyani N, Manalu P, Fauzi MA, Sumardamto P, Kusumowardhani N (2013) Teak agroforestry systems for livelihood enhancement, industrial timber production, and environmental rehabilitation. For Trees Livelihoods 22:241-256

Roshetko JM, Snelder DJ, Lasco RD, Noordwijk MV (2008) Future challenge: a paradigm shift in the forestry sector. In: Snelder DJ, Lasco RD (eds) Smallholder tree growing for rural development and environmental services: lessons from Asia. Springer, Dordrecht, pp 453-485

Ruel MT, Alderman H (2013) Nutrition-sensitive interventions and programmes: how can they help to accelerate progress in improving maternal and child nutrition? Lancet 382:536-551

Sanchez PA (1999) Delivering on the promise of agroforestry. Environ Dev Sustain 1:275-284

Sasaoka M, Laumonier Y, Sugimura K (2014) Influence of indigenous sago-based agriculture on local forest landscapes in Maluku, East Indonesia. J Trop For Sci 26:75-83

Sabastian G, Kanowski P, Race D, Williams E, Roshetko JM (2014) Household and farm attributes affecting adoption of smallholder timber management practices by tree growers in Gunungkidul Region, Indonesia. Agrofor Syst 88:257-268

Singh AK (2018) Prospective of rubber-based agroforestry on Swidden fallow for synergizing climate change mitigation and adaptation. Trop Ecol 59:605-618

Sutardi B, Hilman D (2007) Indonesia country report: climate variability and climate changes, and their implication. Indonesia Ministry of Environment, Jakarta

Suthari S, Prasad MNV (2016) Moringa Oleifera: a potential agroforestry tree that can meet the nutritional requirements of rural people. In: Dagar JC, Tewari JC (eds) Agroforestry research and development. Nova Publishers, New York, pp 489-512

Suyanto S, Khususiyah N, Leimona B (2007) Poverty and environmental services: case study in Way-Besai Watershed, Lampung Province, Indonesia. Ecol Soc 12:13-27

Tabuti JRS, Dhillion SS, Lye KA (2003) Firewood use in Bulamogi County, Uganda: species selection, harvesting and consumption patterns. Biomass Bioenerg 25:581-596 
Tan KH (2008) Soils in the humid tropics and monsoon region of Indonesia. CRC Press, Boca Raton

Toth GG, Nair PKR, Duffy CP, Franzel SC (2017a) Constraints to adoption of fodder tree technology in Malawi. Sustain Sci 12:641-656

Toth G, Nair PKR, Jacobson M, Widyaningsih Y, Duffy CP (2017b) Malawi's energy needs and agroforestry: adoption potential of woodlots. Hum Ecol 45:735-746

Toth GG, Nair PKR, Jacobson M, Widyaningsih Y, Duffy CP (2019) Malawi's energy needs and agroforestry: influences on traditional fuelwood markets. Energy Sustain Dev 50:101-108

UNICEF (2020) UNICEF data: cross-sector indicators. UNICEF, New York. https://data.unicef.org/resources/data_explorer/ unicef_f/?ag=UNICEF\&df=GLOBAL_DATAFLOW\&ver

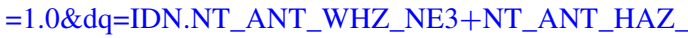
NE2+NT_ANT_WHZ_NE2+NT_ANT_SAM_T..\&start Period=2016\&endPeriod=2020. Accessed May 2020

Waldron A, Garrity D, Malhi Y, Girardin C, Miller DC, Seddon N (2017) Agroforestry can enhance food security while meeting other sustainable development goals. Trop Conserv Sci 10:1-6

Weingartner L (2004) The concept of food and nutrition security. German Corp Intl Coop, Bonn

WFP (2015) Food security and vulnerability atlas of Indonesia. Food Security Council, Indonesian Ministry of Agriculture $\&$ the World Food Programme, Jakarta

Wheeler T, Von Braun J (2013) Climate change impacts on global food security. Science 341:508-513
Wibawa G, Hendratno S, van Noordwijk M (2005) Permanent smallholder rubber agroforestry systems in Sumatra, Indonesia. In: Palm C, Vosti SA, Sanchez PA, Ericksen PJ (eds) Slash-and-burn agriculture: the search for alternatives. Columbia University Press, New York, pp 222-232

Widianingsih NN, Schmidt LH, Theilade I (2019) Jernang (Daemonorops spp.) commercialization and its role for rural incomes and livelihoods in Southern Sumatra, Indonesia. For Trees Livelihood 28:143-159

Wollenberg E, Nawir AA (2005) Turning straw into gold: specialization among damar agroforest farmers in Pesisir, Sumatra. For Trees Livelihood 15:317-336

World Bank (2011) Climate risk and adaptation country profile: Indonesia. World Bank, New York

World Bank (2017) World development indicators: Indonesia. World Bank, Washington DC

World Bank (2019) Indonesia overview. World Bank, New York

World Bank (2020) Agriculture, forestry, and fishing, value added (\% of GDP). https://data.worldbank.org/indicator/ NV.AGR.TOTL.ZS. Accessed May 2020

Zhang W, Ricketts TH, Kremen C, Carney K, Swinton SM (2007) Ecosystem services and dis-services to agriculture. Ecol Econ 64:253-260

Publisher's Note Springer Nature remains neutral with regard to jurisdictional claims in published maps and institutional affiliations. 